\title{
IMPROVING STUDENTS' READING COMPREHENSION BY USING MAKE A MATCH TECHNIQUE AT THE EIGHT GRADE STUDENTS' OF MTS AL FATTAH BANYUURIP UJUNGPANGKAH GRESIK
}

\author{
Abdullah Farih \\ abdullahfarih@unisla.ac.id \\ Universitas Islam Lamongan
}

\begin{abstract}
Reading is a cognitive process of decoding symbols in order to construct or derive meaning (reading comprehension). The objective of this study is to know the application of Make a Match Techniqueto improve the students' reading comprehension at the Eight grade students of MTs Al Fattah Banyuurip Ujungpangkah Gresik and to know whether Make a Match Technique is able to improve the students' reading comprehension in descriptive text. The study was conducted at MTs Al Fattah Banyuurip Ujungpangkah Gresik. The subject of this study was 23 student. This study used Classroom Action Research (CAR) design. The research used pre-test, post-test and observation checklist.To know the students' improvement in reading comprehension, the researcher uses instruments are test and observation checklist. From the result observation checklist it shows that teaching learning by using Make a Match technique can improve succesfully the students' reading comprehension. The average of preliminary test is 56.82, the result of test cycle I is 73.21 and theb result of cycle II is 78.34 .
\end{abstract}

Keyword:teaching reading comprehension, descriptive text, Make a Match

\section{INTRODUCTION}

Based on the limitation of the problems, the research problem can be formulated as follow: 1). How is the application Make a Match Technique used in teaching reading comprehension at the Eight grade students of MTs Al Fattah Banyuurip Ujungpangkah Gresik? And 2). Is Make a Match able to improve the students' reading comprehension in descriptive text?

In this study, the researcher is the theory used reading comperehension and make a match technique. Reading is a cognitive process of decoding symbols in order to construct or derive meaning (reading comprehension). It is a mean of language acquisition of communication and sharing information and ideas.

According to Zare (2012; 188) Reading is a cognitive activity in whichthe reader takespart in a conversation withthe author through the text. Onthe other hand,reading strategies are considered as one of the features of cognitive psychologywhich are essential for a successful comprehension.Reading has many type, every type has different definition. According to cahyono (2011:60), there are 2 types of reading :a). Intensive reading is normally conducted in the classroom, uses a relatively short text accompanied by tasks, and is conducted with the help and/or intervention of a teacher. Such a reading practice will be unable to promote learners' language development (Davis, 1995 as cited in Harmer, 2001:204). b). Extensive reading not given much attention in the school system, it is usually included as one of the major subjects in some English departement. Extensive reading suggest reading at length, often for pleasure and in a leisurely way. It is conducted outside the classroom such as at the self-access centre and library (that is,places where learners can get the reading material), and at home.

Generally, the main purpose reading is to obtain informatiom from the text. According to Grabe (2009:10), the purpose of reading are: One of the most important factors in reading comprehension abilities 
is how reading processes vary depending on the reading purpose. It is clear that reading for entertainment is quite different from reading to learninformation or reading to integrate information from multiple sources. It is also clear that skimming a text for a very general idea involves distinct skill combinations from reading for main idea comprehension, the latter being by far the most common type of reading carried out by fluent readers. A critical factor in teaching L2 reading is helping students understand that different tasks and different activities involve differing levels of demand on comprehension. Some tasks require a high level of detailed comprehension. Other tasks may involve the understanding of main ideas and some supporting information.

Based on theory used above, the researcher use make a match technique to active learning student. Make a Match technique is one of alternative technique that can be applied student. This is one of the cooperative learning techniques that can be applied in the classroom. This technique is started from the technique when the students asked to find their card partner. They have to find the partner before the time limit, student who can find the partner will get point.

$$
\text { According to Hamid }
$$

(2011:228):Make a match technique is interesting techniquewhich used to review the materials givenbefore. But, the new material can also be taught in this strategy with note, the studentsgiven exercise to study the topic that will be taught first, so when enter the class they havehad knowledge.

Make a Match is one of cooperative learning technique that is developed by Curran (1994).It is learning using card. It consists of questions card and the other consist of answer from the question (Supriyono, 2009:94). This model can generate student learners to engage actively in learning process. In case, students look for couple while they study a certain topic or concept at the same time in pleasant atmosphere. This technique can be applied for all class level and subject.

\section{METHOD}

In this study, the researcher used make a match technique to improving reading comprehension. In this research, researcher used the classroom action research (CAR). This is based upon the reason that the researcher attempted to solve the practical problem faced in the classroom. This study used collaborative CAR (Classroom Action Research) design approach was implemented. According to Arikunto(2010:105), classroom action research (CAR) is an approach to improve the education to make changes toward the repairs against the results of education in the learning.The researcher with the classroom teacher planned the action, implemented the action, observed the action and reflected the action

To obtain the valid data, the researcher used kinds of collectiondata. For conducting the research, the researcher used four ways of collecting data. The instrument required in this study They are:a). Observation Checklist and Test. The Observation checklist is required to observe the teachers' performances by using observation sheet during the process of implementing of Make a Match technique in the reading comprehension activities.The researcher interacted with the students as well as teacher, in reading comprehension lesson, researcher observed their reading comprehension.b). Testis manner teacher giving a task to know the students' reading comprehension and to see progress of their reading comprehension before and after teaching and learning process. In every meeting, the researcher also assigns students activities of the reading comprehension task. So, the researher can know the students who their reading comprehension. Such as assign students in the form of a written as test for example, the teacher provides descriptive text and question in the essay form. 


\section{RESULT}

In this study, the researcher gave implementation for 2 meeting using Make match, and than the researcher gave a test a cycle I. This test is given to know students reading comprehension in first cycle is improved or not from the preliminary test.

Table. The Result of Cycle I

\begin{tabular}{clcl}
\hline No & \multicolumn{1}{c}{ Name } & Score & Note \\
\hline 1 & Student 1 & 70 & Failed \\
2 & Student 2 & $\mathbf{8 0}$ & Passed \\
3 & Student 3 & 73 & Failed \\
4 & Student 4 & 73 & Failed \\
5 & Student 5 & $\mathbf{8 3}$ & Passed \\
6 & Student 6 & $\mathbf{7 5}$ & Passed \\
7 & Student 7 & 73 & Failed \\
8 & Student 8 & 70 & Failed \\
9 & Student 9 & 68 & Failed \\
10 & Student 10 & 73 & Failed \\
11 & Student 11 & $\mathbf{7 8}$ & Passed \\
12 & Student 12 & 70 & Failed \\
13 & Student 13 & 65 & Failed \\
14 & Student 14 & 68 & Failed \\
15 & Student 15 & 73 & Failed \\
16 & Student 16 & $\mathbf{8 0}$ & Passed \\
17 & Student 17 & 68 & Failed \\
18 & Student 18 & $\mathbf{7 5}$ & Passed \\
19 & Student 19 & 73 & Failed \\
20 & Student 20 & 68 & Failed \\
21 & Student 21 & 70 & Failed \\
22 & Student 22 & $\mathbf{8 5}$ & Passed \\
23 & Student 23 & 73 & Failed \\
\hline & TOTAL & 1684 & \\
\hline & AVERAGE & 73.21 & \\
\hline
\end{tabular}

Based on the table of the result of the first cycle above, it means that theresearcher should repeated there are $73.21 \%$ of student scored above KKM $>75$,there are 16 students who not pass the score below KKM. So in this second cycle of use Make a Match to improve the student's reading comperehension was successful.

In the step the researcher give treatment for 2 meetings using Make a Match technique, after that the researcher give test in cycle II. This test is give to determine students skills in eading comprehension from the first cycle to improved or not. The result of the evaluation test in cycle II.
Table. The result of Cycle II

\begin{tabular}{|c|c|c|c|}
\hline No & Name & Score & Note \\
\hline 1 & Student 1 & 80 & Passed \\
\hline 2 & Student 2 & 80 & Passed \\
\hline 3 & Student 3 & 75 & Passed \\
\hline 4 & Student 4 & 80 & Passed \\
\hline 5 & Student 5 & 83 & Passed \\
\hline 6 & Student 6 & 75 & Passed \\
\hline 7 & Student 7 & 78 & Passed \\
\hline 8 & Student 8 & 78 & Failed \\
\hline 9 & Student 9 & 75 & Passed \\
\hline 10 & Student 10 & 78 & Passed \\
\hline 11 & Student 11 & 78 & Passed \\
\hline 12 & Student 12 & 78 & Passed \\
\hline 13 & Student 13 & 80 & Passed \\
\hline 14 & Student 14 & 75 & Failed \\
\hline 15 & Student 15 & 78 & Passed \\
\hline 16 & Student 16 & 80 & Passed \\
\hline 17 & Student 17 & 80 & Failed \\
\hline 18 & Student 18 & 75 & Passed \\
\hline 19 & Student 19 & 80 & Passed \\
\hline 20 & Student 20 & 78 & Passed \\
\hline 21 & Student 21 & 75 & Passed \\
\hline 22 & Student 22 & 88 & Passed \\
\hline \multirow[t]{3}{*}{23} & Student 23 & 75 & Passed \\
\hline & TOTAL & 1802 & \\
\hline & AVERAGE & 78.34 & \\
\hline
\end{tabular}

Based on the result ofthe test in Cycle II above, it means that in the second cycle there are of students scored above KKM (>75), it is calculated 20 students. There are only 3 student not pass the score below KKM. So, in this second cycle of use Make a Match to increase the students' reading comprehension was successful.

\section{DISCUSSSION}

The researcher and collaborator observe the teachers' activity in teaching and learning process appropriated with observation checklist.In observation checklist, many indicator did by teacher. Indicator covered three procedures, they are : pre-activity, while-activity and postactivity. There pre-activity covered : The teacher opens the class and greets the students, Checked students' attendance, and the teacher told students the topic of the day. While-activity covered: the teacher explain about descriptive text, after that explained the learning by using Make a Match technique,gives sentence cuttings card of descriptive text about place with different,gives 15 minutes for every group 
to do this activity, divided the student in groups that consists of 5 until 6 students, the students that have called every group in a change to reading aloud it in front of the class or write the generic structure of every their descriptive text in the blackboard,observes the result and motivated the groups that have not been successful in generic structure, And the teacher evaluated the learning result of the students. The last of procedure was postactivity: Teacher reviews the material Gives suggestion to students to study hard, And then also memorize new material and closses the class.

But it was not succesful, because the researcher as the teacher did not do all of the indicators. The teacher did not success in generic stucture of descriptive text and evaluated the learning result of the students.After the researcher gave implementation for 2 meeting using Make a match, and than the researcher gave a test a cycle I.

In this phase, the researcher implemented Make a Match technique in reading comprehension class. In applied this technique done 2 meetings. The reasearcher is using the same procedure of teaching and learning in reading comprehension using Make a Match technique. But different is theme of descriptive of yesterday to each group. In the first cycle the reasearcher use the theme of place, whereas in the second cycle the researcher use the theme of artist and animal. After implementing the technique finish the teacher held test in cycle II. This test was to know increased or not students reading comperhension.After step the researcher give treatment for 2 meetings using Make a Match technique, after that the researcher give test in cycle II. This test is give to determine students skills in eading comprehension from the first cycle to improved or not. The result of the evaluation test in cycle II.

\section{CONCLUSION}

Based on the conclusions above, the following recommendation that is :For the English teachera).in general and particularly those in SMP Islam Tanfirul Ghoyyi who want to improve the students' reading comprehension achievement by implementation of make a match technique in teaching learning process. b). The teacher should motivate the students to be active by giving interesting material and media of make a match. c. The teacher should give tryout about the technique to the students before she/he implemented the technique.

For the students Reading comprehension is very useful for students, because in reading students can be able to know and understand information about what they read, included reading from descriptive text by using Make a Match. In this technique student can learning active and working group to remember they memoriez. So the students must study read loud be able improve their reading comprehension.

For the other researcher In this study far from perfect but the researcher hoped this study can support the further study that may be used consideration for teaching and learning process in the future.

For the english education In this Make a Match technique the researcher hopes this study can support and advocate apply to improve students' reading comprehension.

\section{REFERENCES}

Arikunto, Suharsimi. (2010), Prosedur Penelitian: Suatu Pendekatan Praktek. Jakarta. Rineka Cipta.

Cahyono, B.Y \&Widiati, U .(2011). The Teaching $O F$ English as a Foreign Languange In Indonesia.Malang : State University of Malang Press.

Cathy, Healy. 2002. Reading: What the Experts Say Fact SheetTheLowdown on the NationalReading Panel. 
E-Link Journal

Vol. 5 No. 1 (2018)

p-ISSN: 2085-1383; e-ISSN: 2621-4156

ParentEducational

AdvocacyTrainingCenter

Curran,

Lorna.

(1994).

MetodePembelajaran Make a

Match. Jakarta: PustakaBelajar

Grabe, William. (2009). Key Issues in L2 Reading DevelopmentNorthern Arizona University.

Grabe, William. (2009). Key Issues in L2 Reading Development. Northern Arizona University.
G. Woolley. (2011), Reading Comprehension: Assisting Children with Learning Difficulties.Springer Science +Business Media B.V.

Supriyono, Agus. (2009). Cooperative Learning. Yogyakarta: PustakaPelajar.

Zare, P. (2013). Exploiring reading strategy use and reading comprehension success among EFL Learners.Marvdasht: Islamic Azad University. 